\title{
Native and exotic oysters in Brazil: Comparative tolerance to hypercapnia
}

\author{
Anthony Moreira $^{\mathrm{a}}$, Etelvina Figueira ${ }^{\mathrm{a}}$, Iracy L. Pecora ${ }^{\mathrm{b}}$, Amadeu M.V.M. Soares ${ }^{\mathrm{a}}$, Rosa Freitas ${ }^{\mathrm{a}, *}$ \\ a Departmento de Biologia \& CESAM, Universidade de Aveiro, Campus Universitário de Santiago, 3810-193 Aveiro, Portugal \\ ' Campus do Litoral Paulista - Instituto de Biociências, Universidade Estadual Paulista “Júlio de Mesquita Filho", Praça Infante Dom Henrique s/n São Vicente, CEP \\ 11330-900 São Paulo, Brazil
}

\section{A R T I C L E I N F O}

\section{Keywords:}

Crassostrea brasiliana

Crassostrea gigas

$\mathrm{pCO}_{2}$

Oxidative stress

ETS

Glutathione

\begin{abstract}
A B S T R A C T
Environmental hypercapnia in shallow coastal marine ecosystems can be exacerbated by increasing levels of atmospheric $\mathrm{CO}_{2}$. In these ecosystems organisms are expected to become increasingly subjected to $p \mathrm{CO}_{2}$ levels several times higher than those inhabiting ocean waters (e.g.: 10,000 $\mu \mathrm{atm}$ ), but still our current understanding on different species capacity to respond to such levels of hypercapnia is limited. Oysters are among the most important foundation species inhabiting these coastal ecosystems, although natural oyster banks are increasingly threatened worldwide. In the present study we studied the effects of hypercapnia on two important oyster species, the pacific oyster $C$. gigas and the mangrove oyster $C$. brasiliana, to bring new insights on different species response mechanisms towards three hypercapnic levels (ca. 1,000; 4,000; 10,000 $\mu$ atm), by study of a set of biomarkers related to metabolic potential (electron transport system - ETS), antioxidant capacity (SOD, CAT, GSH), cellular damage (LPO) and energetic fitness (GLY), in two life stages (juvenile and adult) after 28 days of exposure.

Results showed marked differences between each species tolerance capacity to hypercapnia, with contrasting metabolic readjustment strategies (ETS), different antioxidant response capacities (SOD, CAT, GSH), which generally allowed to prevent increased cellular damage (LPO) and energetic impairment (GLY) in both species. Juveniles were more responsive to hypercapnia stress in both congeners, and are likely to be most sensitive to extreme hypercapnia in the environment. Juvenile $C$. gigas presented more pronounced biochemical alterations at intermediate hypercapnia $(4,000 \mu \mathrm{atm})$ than $C$. brasiliana. Adult $C$. gigas showed biochemical alterations mostly in response to high hypercapnia $(10,000 \mu \mathrm{atm})$, while adult $C$. brasiliana were less responsive to this environmental stressor, despite presenting decreased metabolic potential.

Our data bring new insights on the biochemical performance of two important oyster species, and suggest that the duration of extreme hypercapnia events in the ecosystem may pose increased challenges for these organisms as their tolerance capacity may be time limited.
\end{abstract}

\section{Introduction}

Shallow coastal marine ecosystems are major contributors in global carbon dioxide $\left(\mathrm{CO}_{2}\right)$ cycling, functioning as both sinks and sources of atmospheric $\mathrm{CO}_{2}$ (Frankignoulle et al., 1998). The $\mathrm{CO}_{2}$ flux between air and water in these ecosystems has received increasing attention under the eminence of global climate change (Cai, 2011; Feely et al., 2010). In brackish and marine waters $p \mathrm{CO}_{2}$ levels can be naturally high (up to $10,000 \mu \mathrm{atm})$, in comparison to that of open ocean seawater (400 $\mu \mathrm{atm})$. This fact raises the question of how the increase of atmospheric $\mathrm{CO}_{2}$ levels expected for the upcoming decades (IPCC, 2013) may further exacerbate high $p \mathrm{CO}_{2}$ levels in seawater of these ecosystems, and how this may affect resident biota (Tomanek et al., 2011; Melzner et al., 2013).
Organisms inhabiting shallow marine water bodies are known to possess compensation mechanisms to withstand elevated $p \mathrm{CO}_{2}$ in seawater (hypercapnia), to prevent deleterious effects of acidification of tissues and body fluids that affect physiological fitness (Burnett, 1997). However, such mechanisms are time limited and may lead to negative energetic trade-offs (Sokolova et al., 2012), alterations in acid-base balance (Lindinger et al., 1984), as well as alterations of oxidative status (Tomanek, 2015; Matoo et al., 2013). Among these faunal inhabitants, bivalves are generally less tolerant to elevated levels of hypercapnia than vertebrates (Melzner et al., 2009), despite possessing adaptive mechanisms to thrive in constantly fluctuating environmental parameters (Ringwood and Keppler, 2002). They can partially compensate for hypercapnia-induced acidosis (Burnett, 1997), through mechanisms such as shell dissolution to increase internal bicarbonate

\footnotetext{
* Corresponding author.

E-mail address: rosafreitas@ua.pt (R. Freitas).
} 
levels (Shirayama and Thornton, 2005; Lannig et al., 2010) and metabolic adjustment (e.g. metabolic arrest, shifts in metabolic pathways) (Michaelidis et al., 2005; Lannig et al., 2010).

Extensive research on the impacts of seawater acidification on marine bivalves have been published (for reviews see Parker et al., 2013; Gazeau et al., 2014), however most studies focus on the effects of projected $\mathrm{CO}_{2}$ levels for open ocean waters (up to $1,000 \mu$ atm by year 2100) (IPCC, 2013), while the effects of seawater acidification on organisms inhabiting shallow coastal ecosystems has been comparatively overlooked, even though in these systems $p \mathrm{CO}_{2}$ can reach significantly higher levels (between 400 and 10,000 $\mu \mathrm{atm}$ ) (Frankignoulle et al., 1998; Cai, 2011; Noriega and Araujo, 2014; Evans et al., 2013). Considering predictions for increased hypercapnia in shallow coastal systems (Melzner et al., 2013), competitive advantages between species may be altered (Byers, 2002), and zoogeographical shifts in species distribution may occur (Somero, 2010). Therefore, it is important to understand different species ability to cope with such stressors in a changing environment (Parker et al., 2013).

Oysters are important ecosystem engineers in estuarine systems worldwide, providing a variety of ecosystem services and holding a high socio-economic value (Grabowski et al., 2012). However, natural oyster reefs have become severely impacted at a global level due to human pressure and need to be protected (Beck et al., 2011). Crassostrea brasiliana is the most important native oyster species occurring in Brazilian estuaries, and is mainly harvested from natural populations, presenting a high socio-economic value, and is especially important for local extractivist communities (Mendonça and Machado, 2010; Neto et al., 2013). Crassostrea gigas, a non-native species to Brazil and virtually distributed all over the world, is currently cultured in the southern state of Santa Catarina, and accounts for over $90 \%$ of the national oyster aquaculture production (Melo et al., 2010). Since the natural occurrence of $C$. gigas in Brazil has already been registered (Melo et al., 2009), special concerns must be risen in order to understand how the increased frequency of climate change related events (e.g. hypercapnia) may influence different species, and shift competitive advantages towards each other.

Hence, the present study aimed to assess how two important oyster species currently harvested in Brazil, the mangrove oyster Crassostrea brasiliana, and the pacific oyster Crassostrea gigas, respond to hypercapnic conditions by assessment of a suit of biochemical markers, bringing new insights on how native and non-native oysters species may perform in an acidified estuary.

\section{Methods}

\subsection{Species collection and experimental setup}

Crassostrea brasiliana specimens were collected from submerged oyster racks in the Cananéia estuary $\left(25^{\circ} 00^{\prime} 29.50^{\prime \prime} \mathrm{S} 48^{\circ} 01^{\prime} 29.35^{\prime \prime} \mathrm{W}\right)$ in the Extractive Reserve of the Mandira (SE Brazil). Crassostrea gigas individuals were obtained from the Laboratory of Marine Molluscs of the University of Santa Catarina (SE Brazil). Juvenile and adult specimens of both species were selected for laboratory exposures. Average shell height of C. brasiliana and C. gigas juveniles was $4.0 \pm 0.8 \mathrm{~cm}$ and $4.2 \pm 0.2 \mathrm{~cm}$ respectively. Average shell height of adults was $7.2 \pm 0.4 \mathrm{~cm}$ for $C$. brasiliana, and $7.8 \pm 0.3 \mathrm{~cm}$ for $C$. gigas.

Experiments took place during April and May 2015 and were performed in separate for each species. Acclimation to laboratory conditions followed one week prior to the beginning of exposures. During this period, juvenile and adult specimens were maintained in separate tanks, in recirculated artificial seawater (Ocean Fish - Prodac ${ }^{\circ}$ ) (pH 7.8; temperature $24^{\circ} \mathrm{C}$, salinity 25) and daily fed with AlgaMac Protein Plus ${ }^{\varpi}\left(10^{9}\right.$ cells $\mathrm{L}^{-1}$ initial cell density). After acclimation, oysters were randomly distributed into testing systems, consisting of $50 \mathrm{~L}$ aquaria with individual filters and circulation pumps (total seawater flow of $500 \mathrm{~L}^{-1}$ ). Each condition was replicated in three separate aquaria, and aquaria were stocked with 4 adults and 8 juveniles each (12 adults and 24 juveniles per condition). Three different hypercapnia levels were tested 1,000 (pH 7.8), 4,000 (pH 7.4) and 10,000 (pH 7.0) $\mu$ atm $p \mathrm{CO}_{2}$. Hypercapnia levels were selected based on maximum $\mathrm{pH}$ recorded during summer (i.e.: pH 7.85) in submerged oyster beds in the Cananéia estuary (Miraldo and Valenti, unpublished data), high hypercapnia $\mathrm{pH}$ $7.0\left(10,000 \mu \mathrm{atm} p \mathrm{CO}_{2}\right)$ based on reported $p \mathrm{CO} 2$ in estuarine systems worldwide (Cai, 2011), and an intermediate hypercapnia level $\mathrm{pH} 7.4$ $\left(4,000 \mathrm{pCO}_{2}\right)$ to assess transient changes between low and extreme hypercapnia, and values reported for hypoxic estuaries (Melzner et al., 2013).

To achieve targeted hypercapnia levels, food grade $\mathrm{CO}_{2}$ was diffused into each aquarium (conditions $\mathrm{pH} 7.4$ and $\mathrm{pH}$ 7.0) through bubble-counter $\mathrm{CO}_{2}$ diffusers, at gas releasing rates that were pre-established for each condition, and regulated through six-needle valves (ISTA Products ${ }^{\circ}$ ) allowing for constant and stable gas flow (Duarte et al., 2015). During the entire experimental procedures, $\mathrm{pH}$ of each tank was measured and checked three times per day (Hanna Instruments ${ }^{\circ}$ ). After acclimation to laboratory conditions, oysters that were exposed to intermediate and high hypercapnia ( $\mathrm{pH} 7.4$ and $\mathrm{pH} 7.0$ respectively) were progressively acclimated to hypercapnia by $-0.2 \mathrm{pH}$ units per day until targeted $\mathrm{pH}$ values were achieved. This procedure added 4 extra days of acclimation time to each testing group.

After $\mathrm{pH}$ equilibration in testing aquaria, exposures carried on for 28 days. During this period water parameters (temperature, dissolved oxygen, salinity) were daily monitored (YSI Pro plus ${ }^{\circ}$ ). Faecal debris were removed prior to feeding (AlgaMac Protein Plus ${ }^{\circ}$ ) 5 days a week, giving partial water renewals of $5 \%$. Oysters were checked for mortality on a daily basis. Water samples were collected every week, prior to total water renewals to determine total alkalinity (TA) for each aquarium by potentiometric titration (Gran, 1952) with an automatic titrator (Mettler Toledo ${ }^{\circ}$ ). Determined TA for each aquarium was plotted against $\mathrm{pH}$, temperature and salinity average values measured during each week on CO2SYS software, to determine carbonate system variables (Robbins et al., 2010), using dissociation constants K1 and K2 from Mehrbach et al. (1973) refit by Dickson and Millero (1987) and $\mathrm{KSO}_{4}$ from Dickson (1990) (Table 1).

At the end of the experiment ( 28 days), oysters were frozen at $-80{ }^{\circ} \mathrm{C}$ until further analysis.

Table 1

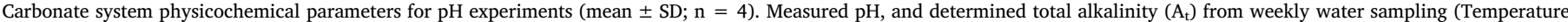

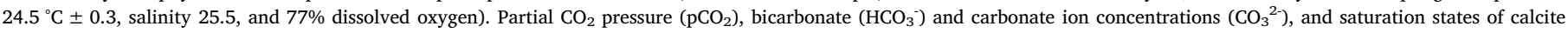
$(\Omega \mathrm{Cal}$ ) and aragonite $(\Omega \mathrm{Ag}$ ), calculated with CO2SYS software (Robbins et al., 2010).

\begin{tabular}{|c|c|c|c|c|c|c|c|c|}
\hline & Condition & $\mathrm{pH}$ & $\mathrm{A}_{\mathrm{t}}\left(\mu \mathrm{mol} . \mathrm{Kg}^{-1}\right)$ & $\mathrm{pCO}_{2}(\mu \mathrm{atm})$ & $\mathrm{HCO}_{3}{ }^{-}\left(\mu \mathrm{mol} . \mathrm{kg}^{-1}\right)$ & $\mathrm{CO}_{3}^{2-}\left(\mu \mathrm{mol} . \mathrm{kg}^{-1}\right)$ & $\Omega \mathrm{Cal}$ & $\Omega$ Ara \\
\hline \multirow[t]{3}{*}{ C. gigas } & pH 7.8 & $7.78 \pm 0.03$ & $2,087 \pm 88$ & $1,182 \pm 76$ & $1937 \pm 99$ & $69.0 \pm 6.3$ & $1.8 \pm 0.2$ & $1.1 \pm 0.1$ \\
\hline & $\mathrm{pH} 7.4$ & $7.38 \pm 0.02$ & $2,679 \pm 115$ & $3,927 \pm 305$ & $2591 \pm 113$ & $37.5 \pm 2.1$ & $1.0 \pm 0.1$ & $0.6 \pm 0.04$ \\
\hline & pH 7.0 & $7.01 \pm 0.04$ & $2,881 \pm 107$ & $10,101 \pm 862$ & $2840 \pm 105$ & $17.7 \pm 1.9$ & $0.5 \pm 0.05$ & $0.3 \pm 0.03$ \\
\hline \multirow[t]{3}{*}{ C. brasiliana } & pH 7.8 & $7.78 \pm 0.02$ & $1,919 \pm 109$ & $1,068 \pm 66$ & $1764 \pm 101$ & $63.6 \pm 5.2$ & $1.7 \pm 0.14$ & $1.1 \pm 0.09$ \\
\hline & pH 7.4 & $7.38 \pm 0.04$ & $2,508 \pm 175$ & $3,751 \pm 423$ & $2428 \pm 170$ & $34.4 \pm 4.1$ & $0.9 \pm 0.1$ & $0.6 \pm 0.07$ \\
\hline & $\mathrm{pH} 7.0$ & $7.00 \pm 0.04$ & $2,789 \pm 105$ & $9,992 \pm 1010$ & $2751 \pm 104$ & $16.7 \pm 1.5$ & $0.4 \pm 0.04$ & $0.3 \pm 0.03$ \\
\hline
\end{tabular}




\subsection{Biochemical analysis}

For biochemical analysis, each juvenile and adult oyster from each species was individually and manually homogenized with a mortar and a pestle under liquid nitrogen. Homogenates from each specimen were further separated in aliquots $(0.1 \mathrm{~g}$ for juveniles, $0.5 \mathrm{~g}$ for adults) to perform individual extractions for each parameter analyzed. For the electron transport system (ETS) activity assay, supernatants were extracted in $0.1 \mathrm{M}$ Tris- $\mathrm{HCl}$ buffer $(15 \%(\mathrm{w} / \mathrm{v})$ polyvinylpyrrolidone (PVP); $153 \mathrm{mM}$ magnesium sulfate $\left(\mathrm{MgSO}_{4}\right) ; 0.2 \%(\mathrm{v} / \mathrm{v})$ Triton X-100) (pH 8.5). For superoxide dismutase (SOD), catalase (CAT) and glycogen (GLY) assays, supernatants were extracted in phosphate buffer $50 \mathrm{mM}$ sodium dihydrogen phosphate monohydrate; $50 \mathrm{mM}$ disodium hydrogen phosphate dehydrate; $1 \mathrm{mM}$ ethylenediamine tetraacetic acid disodium salt dihydrate (EDTA); 1\% (v/v) Triton X-100; 1\% (v/v) (PVP); $1 \mathrm{mM}$ dithiothreitol (DTT) (pH 7.0). For reduced (GSH) and oxidized (GSSG) glutathione quantification assays, extraction buffer consisted of $0.6 \%$ sulfosalicylic acid in potassium phosphate buffer ( $0.1 \mathrm{M}$ dipotassium phosphate, $0.1 \mathrm{M}$ potassium dihydrogen phosphate, 5 mM EDTA, $0.1 \%$ Triton X-100, pH 7.5). For LPO assay supernatants were extracted in $20 \%(\mathrm{v} / \mathrm{v})$ trichloroacetic acid (TCA).

Specific buffers were added to aliquots in a 2:1 vol: weight ratio, and homogenates sonicated for $15 \mathrm{~s}\left(55 \mathrm{~W} \mathrm{~cm}^{-2}\right.$ at $\left.4{ }^{\circ} \mathrm{C}\right)$, and centrifuged for $15 \mathrm{~min}$ at $3,000 \mathrm{~g}$ (for ETS activity) or 10,000 (for the remaining biomarkers) at $4{ }^{\circ} \mathrm{C}$.

Supernatants were stored $\left(-80^{\circ} \mathrm{C}\right)$ or directly used to measure: ETS activity; ii) SOD and CAT activities; iv) GSH and GSSG concentrations; v) LPO; vi) GLY content; vii) protein content.

Biomarkers were assessed at room temperature $\left(22^{\circ} \mathrm{C}\right)$ using analytical grade reagents for all analyses. Enzymatic activities (ETS, SOD, CAT) and glutathione (GSH and GSSG) content were standardized by protein concentration of each sample. Protein was quantified by the Biuret method (Robinson et al., 1940), using bovine serum albumin (BSA) as standard. Results on LPO and GLY were standardized by samples fresh weight (FW).

\subsubsection{Electron transport system}

The ETS activity was measured according to King and Packard (1975) and modifications introduced by Coen and Janssen (1997). Reaction mixture consisted of $0.13 \mathrm{M}$ Tris-HCL buffer (pH 8.5, 0.3\% (v/ v) Triton X-100), $0.25 \mathrm{mM} \mathrm{NADH}, 36.5 \mu \mathrm{M} \mathrm{NADPH}$, and $2.3 \mathrm{mM}$ INT (2-(4-Iodophenyl)-3-(4-nitrophenyl)-5-phenyltetrazolium Chloride). Formazan production rate was determined spectrophotometrically at $490 \mathrm{~nm}$ during $10 \mathrm{~min}$ ( $25 \mathrm{~s}$ intervals), and determined using $\varepsilon=$

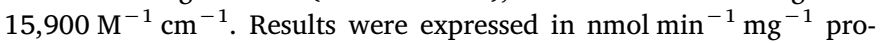
tein.

\subsubsection{Antioxidant scavengers}

SOD activity was quantified following Beauchamp and Fridovich (1971) using SOD standard $0.25-60 \mathrm{U} \mathrm{mL}^{-1}$. Reaction mixture consisted of phosphate buffer $50 \mathrm{mM}$ (pH 8.0), $68.4 \mu \mathrm{M}$ NBT (nitroblue tetrazolium chloride), $0.1 \mathrm{mM}$ DTPA (diethylenetriamineppent-acetic acid), $0.1 \mathrm{mM}$ hypoxanthine. Enzyme activity was determined at $560 \mathrm{~nm}$ in a microplate reader after adding xanthine oxidase (5 mU), diluted in phosphate buffer $50 \mathrm{mM}$ (pH 8.0). Absorbance was measured after 20 min incubation at $22{ }^{\circ} \mathrm{C}$, and the rate of NBT reduction determined. SOD activity was expressed in $\mathrm{U} \mathrm{mg}^{-1}$ protein $(\mathrm{U}=$ $\mu \mathrm{mol} \min ^{-1}$ ).

CAT activity was determined according to Johansson and Håkan Borg (1988), using formaldehyde as standard (0-150 $\mu \mathrm{M})$. Reaction was made in phosphate buffer ( $\mathrm{pH} 7.0$ ), 5.6 M methanol, and the presence of $35.28 \mathrm{mM} \mathrm{H}_{2} \mathrm{O}_{2}$. Reaction was stopped by adding $10 \mathrm{M} \mathrm{KOH}$ and $34.2 \mathrm{mM}$ purpald. Absorbance was measured at $540 \mathrm{~nm}$ in a microplate reader. CAT activity was expressed in $\mathrm{Umg}^{-1}$ protein $(\mathrm{U}=$ nmol $\min ^{-1}$ ).

GSH and GSSG were determined spectrophotometrically at $412 \mathrm{~nm}$ following Rahman et al. (2007), using analytical grade (GSH and GSSG) standards $\left(0-60 \mu \mathrm{mol} \mathrm{L}^{-1}\right)$. GSH and GSSG concentrations (nmol mg $\operatorname{prot}^{-1}$ ) were further expressed as a ratio (GSH/GSSG) and as total glutathione (tGSH), considering the number of thiol equivalents (GSH/ GSSG $=[\mathrm{GSH}] / 2 \mathrm{x}[\mathrm{GSSG}])$, and $(\mathrm{tGSH}=[\mathrm{GSH}]+2 \mathrm{x}[\mathrm{GSSG}])$ (Rahman et al., 2007).

\subsubsection{Cellular damage}

LPO levels were quantified following an adaptation of the thiobarbituric acid (TBA) assay from Buege and Aust (1978). Reaction mixture consisted of TBA at $5 \%(\mathrm{v} / \mathrm{v})$ in TCA at $20 \%(\mathrm{v} / \mathrm{v})$. Samples were incubated at $96{ }^{\circ} \mathrm{C}$ for $30 \mathrm{~min}$ and then cooled on ice. Absorbance was measured at $535 \mathrm{~nm}\left(\varepsilon=156 \mathrm{mM}^{-1} \mathrm{~cm}^{-1}\right)$. LPO levels were expressed in nmol MDA $\mathrm{g}^{-1} \mathrm{FW}$.

\subsubsection{Energy reserves}

GLY content was determined following Yoshikawa (1959), using glucose as standard $(0-5 \mathrm{mg} / \mathrm{mL})$. Samples were incubated at room temperature for $30 \mathrm{~min}$ after reacting with phenol (5\%) and sulphuric acid (98\%). Absorbance was measured at $492 \mathrm{~nm}$, and GLY content expressed in $\mathrm{mg} \mathrm{g}^{-1} \mathrm{FW}$.

\subsection{Biochemical data analysis}

Biochemical parameters (ETS, GLY, SOD, CAT, GSH/GSSG; tGSH LPO) were submitted to hypothesis testing using permutational analysis of variance, employing the PERMANOVA+ add-on in PRIMER v6 (Anderson et al., 2008).

Parameters were analyzed following a one-way hierarchical design, with hypercapnia level for juvenile or adult oyster, of each species as the main fixed factor. Concerning each descriptor, null hypothesis tested were: $\mathrm{H}_{0}$ ') for each species and each life stage (juvenile or adult), no significant differences exist among hypercapnic levels; $\mathrm{H}_{0}$ ") for each hypercapnic level, and for each species no significant differences exist between life stages; $\mathrm{H}_{0}$ "') at each condition and life stage no significant differences exist between species.

Data for each biomarker are presented as mean + standard deviation. Significant differences ( $p \leq 0.05$ ) among groups representing each condition were identified in figures with different letters (minuscule for juvenile, and majuscule for adult specimens). At each hypercapnic level, significant differences between juvenile and adults of each species were represented with an asterisk. Comparative analyses between species are given in Supplementary table I, as Monte-Carlo $p$-values for each biomarker.

\section{Results}

\subsection{Electron transport system activity}

Results obtained concerning the ETS activity for both species are depicted in Fig. 1. Juvenile and adult $C$. gigas presented an increase of ETS activity with the increase of hypercapnia, with significant differences towards control ( $\mathrm{pH} 7.8)$ at the intermediate hypercapnic level (7.4) in juveniles, and at the highest hypercapnic level ( $\mathrm{pH} 7.0)$ in adults. Comparisons between adult and juvenile metabolic potential showed significantly higher ETS activity in juvenile oysters at the intermediate hypercapnic level ( $\mathrm{pH}$ 7.4) (Fig. 1A).

The ETS activity in C. brasiliana showed a decreasing trend in both juveniles and adults with the increase of hypercapnia (Fig. $1 \mathrm{~B}$ ), with significant differences at both hypercapnic levels ( $\mathrm{pH} 7.4$ and $\mathrm{pH} 7.0$ ) comparing to control ( $\mathrm{pH} 7.8$ ). No significant differences were observed concerning ETS activity between adult and juvenile $C$. brasiliana at each condition (Fig. 1). 


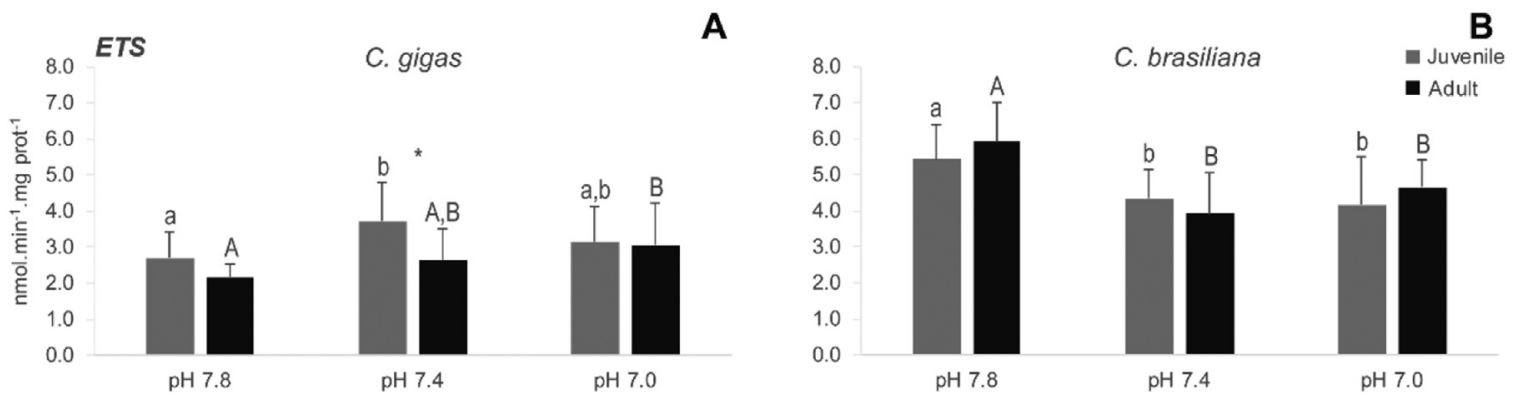

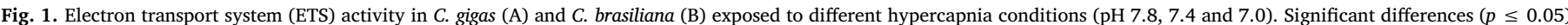

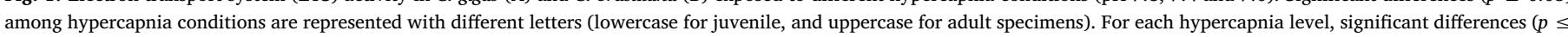
0.05) between juvenile and adult oysters are represented with an asterisk (mean + SD).
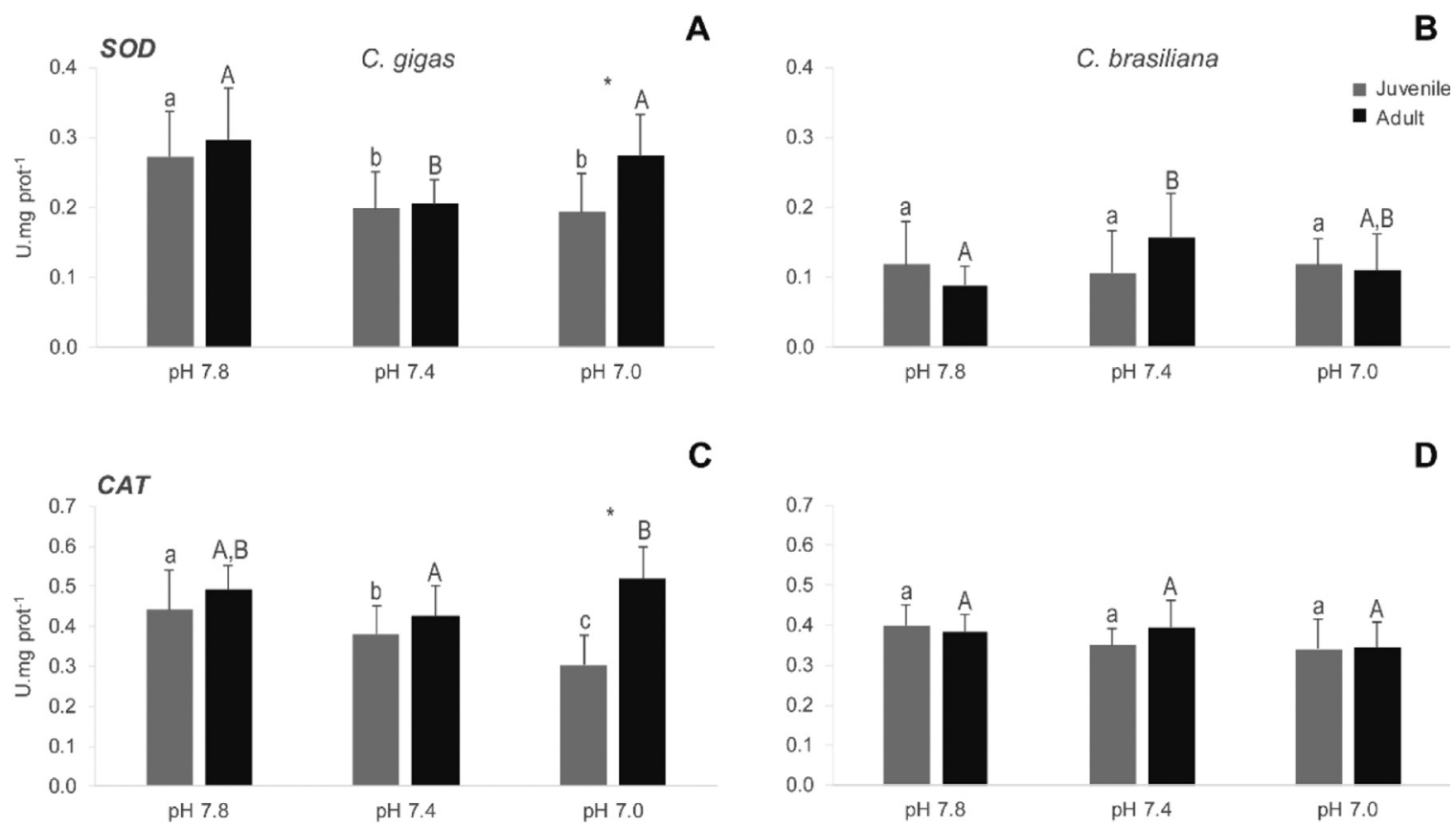

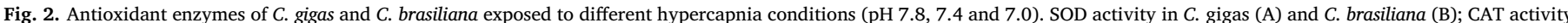

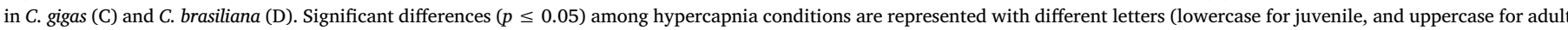
specimens). For each hypercapnia level, significant differences $(p \leq 0.05)$ between juvenile and adult oysters are represented with an asterisk (mean + SD).

\subsection{Antioxidant enzymes}

Results obtained on antioxidant enzymes SOD and CAT activity for both species are presented in Fig. 2. In juvenile $C$. gigas, SOD activity was significantly lower at both hypercapnic levels (pH 7.4 and $\mathrm{pH} 7.0$ ) comparing to control (pH 7.8) (Fig. 2A). Adult C. gigas showed a significant decrease of SOD activity at the intermediate hypercapnic condition ( $\mathrm{pH}$ 7.4) comparing to control. At the highest hypercapnia condition (7.0) SOD activity in adult C. gigas was similar to that observed at control ( $\mathrm{pH}$ 7.8). Comparisons between adult and juvenile SOD activity at each testing condition, showed significantly higher SOD activity in adults at the highest hypercapnic level (pH 7.0) (Fig. 2A).

In juvenile $C$. brasiliana SOD activity was similar among tested conditions (Fig. 2B). In adult C. brasiliana a significant increase of SOD activity was observed at the intermediate hypercapnic condition $(\mathrm{pH}$ 7.4) comparing to control. At the highest hypercapnic level ( $\mathrm{pH} 7.0$ ), SOD activity in adult $C$. brasiliana was not significantly different from neither of the remaining conditions ( $\mathrm{pH}$ 7.0). No significant differences were observed between adult and juvenile SOD activity at each condition (Fig. 2B).

Results obtained on CAT for C. gigas are presented in Fig. 2C. In juveniles, a decrease of CAT activity was observed with the increase of hypercapnia, with significant differences among all testing conditions
(Fig. 2C). Adult oysters presented highest CAT activity at the highest hypercapnic level (pH 7.0), with significant differences towards the intermediate hypercapnia level ( $\mathrm{pH}$ 7.4), but no significant differences to control ( $\mathrm{pH}$ 7.8) (Fig. 2C). Significantly higher CAT activity was observed in adults at highest hypercapnia level ( $\mathrm{pH}$ 7.0) comparing to juveniles (Fig. 2C).

Results obtained concerning CAT activity in $C$ brasiliana (Fig. 2D) showed no significant differences among conditions, concerning juveniles and adult oysters. Comparisons between adult and juvenile CAT activity at each hypercapnia condition showed no significant differences throughout (Fig. 2D).

\subsection{Glutathione redox balance}

Results obtained concerning GSH/GSSG and tGSH for both oyster species are depicted in Fig. 3. Juvenile $C$. gigas presented significantly higher GSH/GSSG at the highest hypercapnic condition (pH 7.0), with significant differences towards both the intermediate hypercapnia level (pH 7.4) and to control (pH 7.8) (Fig. 3A). Adult C. gigas presented no significant differences in GSH/GSSG among conditions. Comparisons between adult and juvenile $C$. gigas at each condition, showed significantly higher GSH/GSSG in juvenile oysters at the highest hypercapnia level ( $\mathrm{pH}$ 7.0) (Fig. 3A). 
A
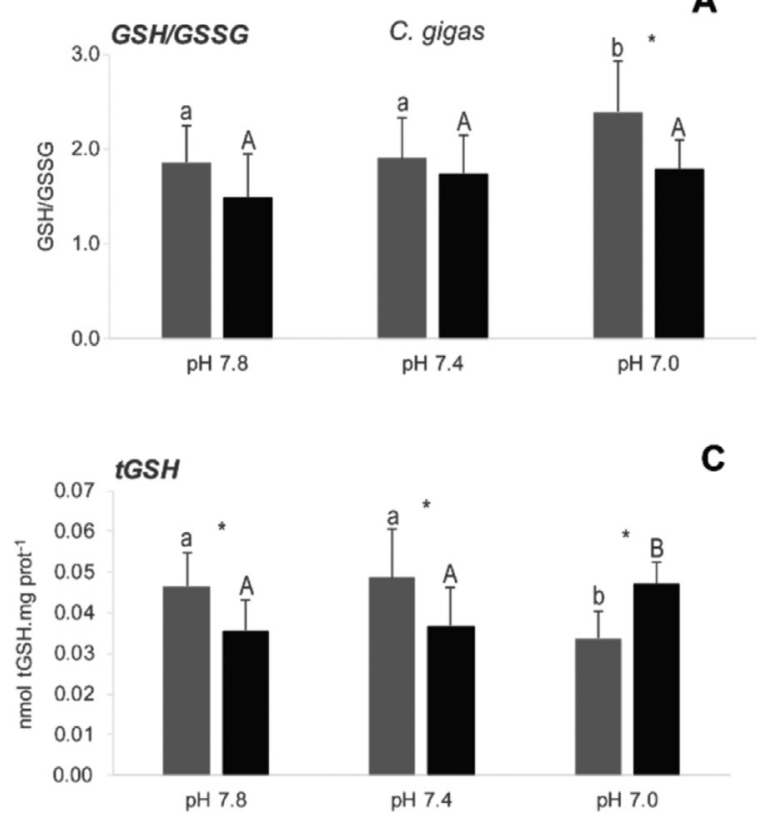

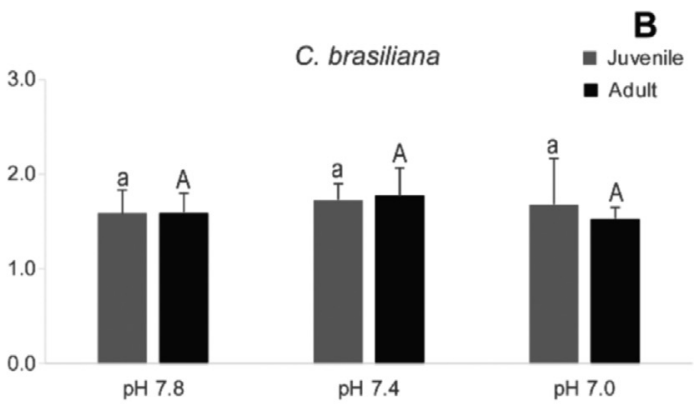

D

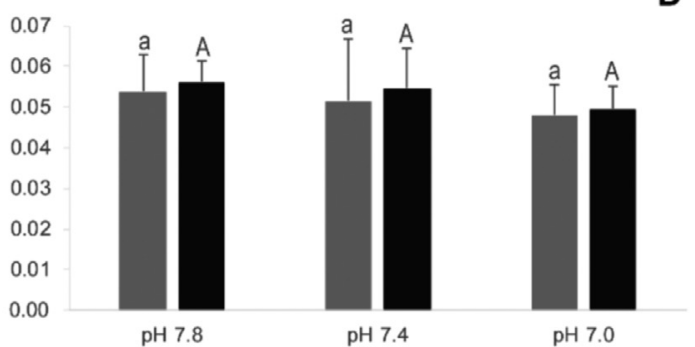

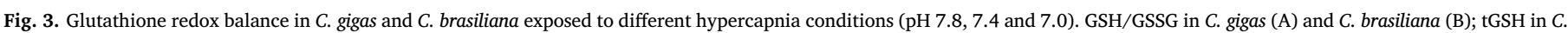

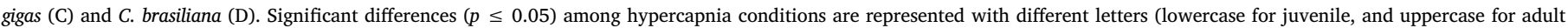
specimens). For each hypercapnia level, significant differences $(p \leq 0.05)$ between juvenile and adult oysters are represented with an asterisk (mean + SD).

Regarding C. brasiliana no significant changes were observed in GSH/GSSG among different conditions for either juveniles nor adults. Moreover, no significant differences were observed between adults and juveniles GSH/GSSG within each condition (Fig. 3B).

Total glutathione content (tGSH) in juvenile C. gigas was significantly lower at the highest hypercapnic level $(\mathrm{pH} 7.0)$ comparing to the remaining conditions (Fig. 3C). In contrast, adult oysters presented significantly higher tGSH at the highest hypercapnic level ( $\mathrm{pH} 7.0)$, compared to the remaining conditions (Fig. 3C). Comparisons between adult and juvenile tGSH at each testing condition, showed significantly higher tGSH in juvenile oysters at low $(\mathrm{pH} 7.8)$ and intermediate $(\mathrm{pH}$ 7.4) hypercapnia, and lower tGSH at the highest hypercapnic level $(\mathrm{pH}$ 7.9) than adults (Fig. 3C).

Concerning C. brasiliana, results obtained showed no significant changes in tGSH content among conditions in either juveniles nor adults exposed to different hypercapnic levels (Fig. 3D). No differences were observed between juvenile and adults tGSH at each testing condition (Fig. 3D).

\subsection{Cellular damage}

Results obtained concerning LPO levels for each species are presented in Fig. 4. In juvenile $C$. gigas LPO was significantly higher at the intermediate hypercapnic level (pH 7.4) compared to that observed in juveniles maintained at low ( $\mathrm{pH} 7.8)$ and high hypercapnic level $(\mathrm{pH}$ 7.0) (Fig. 4A). In adult $C$. gigas no significant differences were observed among testing conditions (Fig. 4A). Comparisons between adult and juvenile LPO levels at each testing condition, showed overall higher LPO in juveniles than in adults, and differences were significant for both hypercapnic conditions (pH 7.4 and pH 7.0) (Fig. 4A).

Regarding C. brasiliana, juvenile oysters presented a significant decrease of LPO levels at the highest hypercapnia level (pH 7.0) in comparison to control and intermediate hypercapnia conditions ( $\mathrm{pH} 7.8$ and pH 7.4) (Fig. 4B). In adult C. brasiliana no significant differences in LPO levels were observed among testing conditions. Comparisons between adult and juvenile oysters at each condition showed significantly higher LPO in juveniles in all hypercapnic levels (Fig. 4B).

\subsection{Energetic fitness}

Results obtained concerning GLY content for both oyster species are presented in Fig. 5. In juvenile C. gigas no significant differences in GLY content were observed among different hypercapnia conditions (Fig. 5A). In adult specimens however, significantly lower GLY content was observed at the highest hypercapnia level $(\mathrm{pH} 7.0)$ in comparison to the remaining conditions (Fig. 5A). Comparisons between adult and juvenile GLY at each condition showed no significant differences among testing conditions (Fig. 5A).
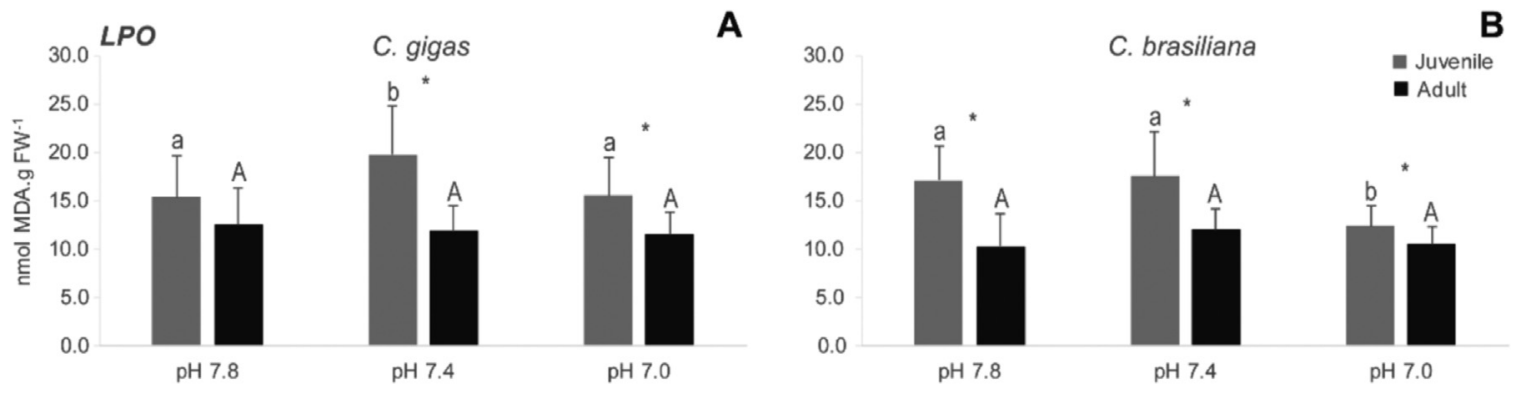

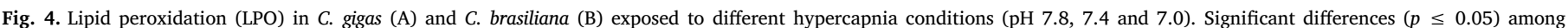

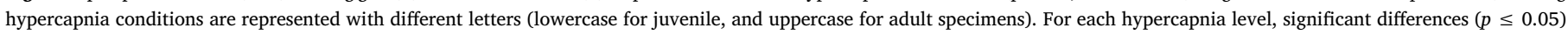
between juvenile and adult oysters are represented with an asterisk (mean +SD). 


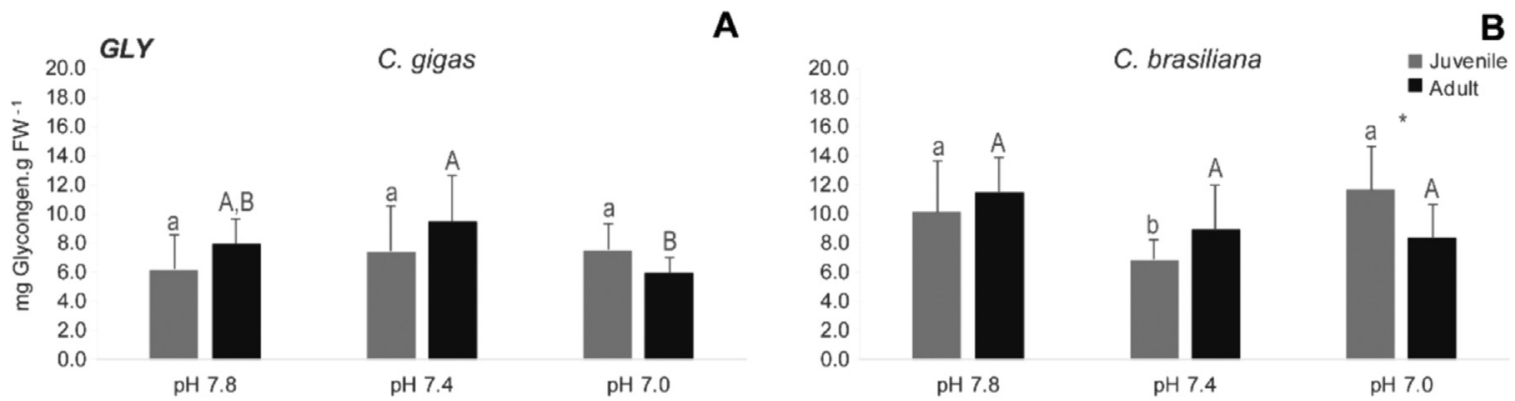

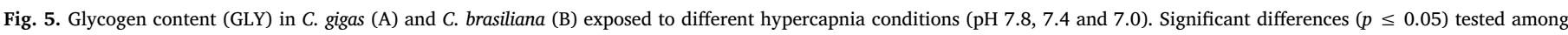

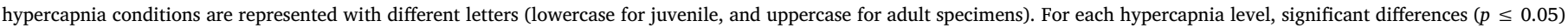
between juvenile and adult oysters are represented with an asterisk (mean + SD).

Concerning C. brasiliana, juveniles presented significantly lower GLY content at the intermediate hypercapnia level (pH 7.4), in comparison to the remaining conditions (Fig. 5B). In adult $C$. brasiliana no significant differences were observed in GLY content among conditions, despite an apparent decreasing trend of GLY with the increase of $p \mathrm{CO} 2$ (Fig. 5B). Differences in GLY content between adult and juveniles at each condition were significant at the highest hypercapnic level, with higher GLY content in juveniles compared to adults (Fig. 5B).

\section{Discussion}

The effects of hypercapnia on marine organisms have been focus of research, despite recent advances indicate that the current understanding of the mechanisms involved is still poor (Tomanek, 2015). The present study assessed the effects of hypercapnia on two oyster species, through a suit of biochemical markers related to previously reported effects of hypercapnia (e.g. metabolic shift, oxidative stress response, energetic fitness), to elucidate different species tolerance capacities to this environmental stressor.

\subsection{Electron transport system}

Ectothermic metazoans exposed to hypercapnia experience tissue and body fluids acidosis, due to diffusive entry of $\mathrm{CO}_{2}$ into the organisms (see Lindinger et al., 1984; Burnett, 1997; Pörtner et al., 1998; Pörtner et al., 2004). So far, studies show that these organisms increase bicarbonate levels in body fluid compartments as a compensatory mechanism to withstand respiratory acidosis (Pörtner et al., 1998; Strobel et al., 2013). In bivalves this is achieved by dissolution of the internal shell (Michaelidis et al., 2005; Harms et al., 2014). However, the increase of bicarbonate levels can competitively inhibit citrate synthase and, therefore, constrain the tricarboxylic acid cycle (TCA) (Simpson, 1967). This has recently been pointed as one of the drivers for metabolic adjustment in aquatic organisms as a response to hypercapnia, given that the inhibition of the first step of oxidative phosphorylation (citrate synthase) elicits the need for alternative anaplerotic pathways (Strobel et al., 2013; Langenbuch and Pörtner, 2003). Marine bivalves may shift to decarboxylation of amino-acids instead of pyruvate for respiration (Müller et al., 2012), thus altering the electron transport chain functioning, by changing preferential subtracts for energetic turnover (Müller et al., 2012; Tomanek, 2015).

Results obtained in the present study showed alterations of metabolic performance of oysters under hypercapnic conditions, measured by the activity of the electron transport system (ETS). This biomarker gives a proxy of maximum potential metabolic activity (Schmidlin et al., 2015), and has been employed to study the influence of several abiotic factors on oyster metabolism (e.g.: Le Moullac et al., 2007; García-Esquivel et al., 2002; Moreira et al., 2017).

The increase of ETS activity observed in $C$. gigas (adults and juveniles) with the increase of $p \mathrm{CO}_{2}$, indicate the development of increased metabolic potential in response to hypercapnia in this species. These results are in line with recent studies on other ectothermic marine metazoans exposed to hypercapnia. Strobel et al. (2013) observed increased aerobic capacity (higher activities of citrate synthase and cytochrome oxidase enzymes) in red muscle of Notothenia rossii fish exposed to hypercapnia, and suggested that this could either be a mechanism to sustain elevated costs of acid-base balance regulation, or as a compensation mechanism for alterations in mitochondria metabolism. Similarly, Harms et al. (2014) observed upregulation of ETS related genes in Hyas araneus crab exposed to $>900 \mu \mathrm{atm} p \mathrm{CO}_{2}$, and their results were justified as a mechanism to compensate for increased energetic costs of acid-base maintenance in hypercapnia exposed animals. The ETS activity in $C$. gigas oysters has been shown to increase in conditions of hypoxia (Le Moullac et al., 2007; Samain and McCombie, 2008), and could likely be a common response mechanism triggered by these stressors, since hypoxia and hypercapnia often occur simultaneously in the environment (Willson and Burnett, 2000).

In contrast, $C$. brasiliana presented a decrease of metabolic potential with the increase of hypercapnia, with lower ETS activity in both intermediate and high hypercapnia conditions ( $\mathrm{pH} 7.4$ and 7.0) towards low hypercapnia ( $\mathrm{pH}$ 7.8) in both juvenile and adult specimens, indicating a down regulation of metabolic capacity. Some studies have described metabolic depression in marine invertebrates exposed to high $\mathrm{CO}_{2}$ concentrations (e.g.: Michaelidis et al., 2005; Pörtner et al., 1998; Reipschläger and Pörtner, 1996), which can be indicative of organisms incurring stress (Guppy and Withers, 1999; Lannig et al., 2010; Parker et al., 2013). Metabolic depression in response to hypercapnia can imply shifts in preferential metabolic pathways (Pörtner et al., 2005), as observed for $C$. gigas through shotgun sequencing (Timmins-Schiffman et al., 2014). In the present study, C. brasiliana appears to have achieved a new state in metabolic respiration, with lower potential aerobic capacity after four weeks of exposure to hypercapnic conditions, possibly to reconfigure energetic balance. In a previous study, a decrease in ETS activity was observed in juvenile $C$. brasiliana oysters in response to high temperature and results were explained as trade-off mechanisms to prevent energetic reserves depletion (Moreira et al., 2017). The ETS activity has also been shown to decrease in Scrobicularia plana clams $(p \mathrm{CO} 2>5000 \mu \mathrm{atm})$, and authors suggested these results could relate to metabolic depression to maintain energetic fitness (Freitas et al., 2016).

\subsection{Antioxidant scavengers and cellular damage}

Alterations in mitochondria respiration capacity and electron transport flow through the electron transport chain modulate reactive oxygen species (ROS) production (Harms et al., 2014; Gibbin et al., 2017). Changes in the electron transport chain functioning might also be employed as a defence mechanism to prevent deleterious effects of ROS (see Abele et al., 2007). Hence, the results concerning the ETS activity can influence the overall antioxidant response (SOD and CAT 
activities), glutathione redox status (GSH/GSSG) and ultimately cellular damage (LPO). In C. gigas the increase of ETS activity observed in both hypercapnic conditions, could have induced an increase of ROS production, since complexes I and III of the electron transport chain are major sources of superoxide anion, hydrogen peroxide and hydroxyl radicals (Guzy and Schumacker, 2006; Murphy, 2009). ROS can negatively interact with DNA, proteins, carbohydrates and lipids (see Almeida et al., 2007), however the negative effects of ROS at the cellular level can be mitigated by antioxidant enzymes (SOD and CAT) as well as non-enzymatic antioxidant scavengers (GSH). C. gigas adults showed increased SOD and CAT activities at the highest hypercapnic level $(\mathrm{pH}$ 7.0), which coincided with increased metabolic potential (ETS). SOD and CAT increased activities could have been triggered to mitigate the negative effects of higher ROS production occurring from the mitochondria electron transport chain. Similar relationships between increased ETS and higher antioxidant capacities (SOD and CAT) have been proposed for Crassostrea angulata adult oysters (Moreira et al., 2016) exposed to low salinity. However, at the intermediate hypercapnic level both juvenile and adult $C$. gigas did not present increased antioxidant enzymes activities, despite the increase of the ETS activity (significant only for juveniles), rather lower SOD and CAT activities were observed comparing to low hypercapnia condition $(\mathrm{pH}$ 7.8). It is possible that other antioxidants could have been in play, namely glutathione (GSH), an important non-enzymatic antioxidant scavenger that is a key participant in processes of ROS neutralization (Rahman et al., 2007). Our data suggest that both juvenile and adult $C$. gigas shifted towards the preferential use of GSH as primary detoxification mechanism, despite presenting differentiated capacities. The significant decrease of both reduced (GSH) and oxidized (GSSG) glutathione content observed in juvenile $C$. gigas with the increase of hypercapnia (data not presented), that resulted in lower tGSH levels and higher GSH/GSSG at the highest hypercapnic level, indicate that glutathione was being involved in detoxification mechanisms in response to hypercapnia, as reported for other bivalve species under hypercapnic or hypoxic conditions (Nardi et al., 2017; Khan and Ringwood, 2016). These findings could explain results showing lower SOD and CAT activities in juvenile $C$. gigas at both hypercapnic levels ( $\mathrm{pH} 7.4$; $\mathrm{pH} 7.0$ ), that together indicate a metabolic shift towards glutathione mediated ROS-quenching pathways, as observed in Mytilid species exposed to heat stress (Tomanek, 2014). The increase of GSH/GSSG observed in juveniles at the highest hypercapnia level $(\mathrm{pH} 7.0)$ further indicate oysters were actively transporting glutathione in its oxidized form (GSSG) out of the organism, also reflecting in a lower $t \mathrm{GSH}$ content. Under oxidative conditions, excessive GSSG can react with thiol groups of proteins, a process known as glutathionylation, leading to alterations of protein functioning (Hawkins et al., 2010; Hurd et al., 2005). The loss of cellular GSH/GSSG redox control makes glutathionylation a deleterious event (Ghezzi and Di Simplicio, 2009), and therefore GSSG is generally exported from the cell to the extracellular matrix (Garcia et al., 2010; Han et al., 2006). Given this, our findings suggest that juvenile $C$. gigas antioxidant capacity at the highest hypercapnia level ( $\mathrm{pH}$ 7.0) was exceeded, with excess glutathione oxidation, and GSSG excretion resulting in lower total glutathione content, as seen in other bivalve species experiencing oxidative stress (Hannam et al., 2010; Peña-Llopis et al., 2002 Regoli et al., 1998). Although juveniles appeared to present a preferential use of GSH as major antioxidant defence in detriment of antioxidant enzymes (SOD and CAT), possibly because it is energetically less costly (Pannunzio and Storey, 1988), the capacity to replenish tGSH levels showed to be insufficient at the highest hypercapnic level ( $\mathrm{pH}$ 7.0). In contrast, adult $C$. gigas maintained redox balance (GSH/GSSG) among all hypercapnia conditions, likely due to increased synthesis of glutathione observed (significantly higher GSH at pH 7.0, data not presented). Similarly, Philipp et al. (2008) observed a more pronounced decrease of glutathione in young Aequipecten opercularis scallops than adults after swimming bursts, and postulated that younger animals were less effective on homeostatic regulation.

Overall, results obtained concerning the antioxidant capacity of $C$. brasiliana showed a lower degree of oxidative stress response than $C$. gigas. In C. brasiliana, significant changes in antioxidant enzymes among different conditions were only observed for SOD activity, in adults at the intermediate hypercapnic level. The relatively low antioxidant response observed, as well as the decrease of metabolic potential (ETS) with the increase of hypercapnia observed in $C$. brasiliana (both adults and juveniles), indicate rearrangement of metabolic pathways towards lower ROS production, as suggested by Tomanek (2015). Under extreme environmental conditions, facultative anaerobes such as oysters, may switch to anaerobic metabolism to extend energetic resources until favourable environmental conditions return (Sokolova et al., 2012). This mechanism also allows for a decrease of ROS production (Abele et al., 2007; Anestis et al., 2007; Pörtner, 2010), and has been shown in Mytilus edulis under hypoxia (Rivera-Ingraham et al., 2013). Considering this, our data suggest that $C$. brasiliana developed a depressed metabolic status, preventing excessive ROS production through alterations on the electron transport chain functioning, as well as maintaining energetic balance.

\subsection{Cellular damage}

The antioxidant capacity of each species likely reflects the oxidative status of the entire organism, and could ultimately impact lipid peroxidation (LPO) levels (Almeida et al., 2007). Increased oxidative stress could be expected to occur with the increase of hypercapnia, considering that $\mathrm{CO}_{2}$ can directly induce ROS production (Harms et al., 2014) or indirectly through metabolic rearrangement (TimminsSchiffman et al., 2014; Tomanek, 2015). LPO in adult C. gigas was similar among all tested conditions, indicating that cellular or physiological mechanisms could have been employed to prevent membrane oxidative damage. Indeed, we observed increased SOD and CAT activities at the highest hypercapnia tested, as well as an increase of the glutathione pool (tGSH), which all together may have helped prevent LPO increased formation. By the contrary juvenile $C$. gigas were more susceptible to membrane damage, with an observed increase of LPO levels in oysters exposed to the intermediate hypercapnic level $(\mathrm{pH}$ 7.4), which could have resulted from significantly lower SOD and CAT activities previously discussed. At the highest hypercapnia level $(\mathrm{pH}$ 7.0), LPO in juvenile $C$. gigas was similar to that observed at low hypercapnia ( $\mathrm{pH}$ 7.8), possibly as a result of glutathione mediated ROS quenching capacity (see above). However, tGSH depletion associated to excessive GSSG may be a precursor of increased LPO (Ringwood et al., 1999). Therefore, this mechanism is likely to become time limited for juvenile $C$. gigas.

Concerning C. brasiliana, no change in LPO levels were observed among tested conditions. In juveniles however, lower LPO at the highest hypercapnic level ( $\mathrm{pH}$ 7.0), corroborates the hypothesis that oysters were depressing metabolism, also in accordance with results obtained for ETS activity and antioxidants (SOD, CAT and GSH) previously described. This hypothesis is further supported by RiveraIngraham et al. (2013) studies on M. edulis, that showed decreased ROS production in mussels exposed to anoxia, accompanied by no change in oxidative damage parameters (MDA and protein carbonyl).

\subsection{Energetic fitness}

The energetic status of bivalves can reflect the level of environmental stress (Storey, 1998). Results obtained for C. gigas indicate higher energetic expenditure in adult oysters exposed to the highest level of hypercapnia (pH 7.0) (lower GLY content), consistent with results obtained with high metabolic costs of increased ETS and antioxidant enzymes activities observed at the same condition (SOD and CAT). In contrast, Timmins-Shiffman and co-authors (2014) found no change in GLY content of C. gigas exposed to hypercapnia, although 
testing lower $p \mathrm{CO}_{2}$ levels $(2,800 \mu \mathrm{atm})$ than in the present study. Hence, our results suggest that higher levels of hypercapnia $(10,000 \mu \mathrm{atm})$ may further challenge adult $C$. gigas energetic fitness. In contrast, juvenile oysters presented no change in GLY content among hypercapnic conditions, which could be explained by GSH mediated stress response observed, which can be energetically less costly (Pannunzio and Storey, 1998).

Together, results obtained concerning GLY, ETS and antioxidant capacity in C. gigas (adults and juveniles) indicate hypercapnia induced a transition to a moderate stress status, according to the concept of energy-limited stress tolerance (Sokolova et al., 2012), when an increase of metabolic capacity and energetic turnover occurs as a compensation mechanism for homeostatic maintenance and damage repair in response to a given stressor.

C. brasiliana adult oysters showed no change in GLY content among hypercapnic levels. However, at the intermediate hypercapnia level $\mathrm{pH}$ 7.4) juvenile $C$. brasiliana presented significantly lower GLY content, indicative of oysters enduring energetic burden in response to stress (Sokolova and Lannig, 2008). Energetic reserves expenditure has also been demonstrated in juvenile oysters, namely $C$. brasiliana under thermal stress (Moreira et al., 2017), and Crassostrea virginica under hypercapnia (ca. $800 \mu \mathrm{atm} p \mathrm{CO}_{2}$ ) (Dickinson et al., 2012). At the highest hypercapnic level (pH 7.0) however, high GLY content in juvenile $C$. brasiliana (similar to values at low hypercapnia ( $\mathrm{pH} 7.8$ )), indicate these oysters were under an arrested metabolic state at the highest hypercapnic level ( $\mathrm{pH} 7.0$ ), a mechanism employed to conserve energy also reported in other mollusc species (Michaelidis et al., 2005; Gazeau et al., 2014). The rate of carbohydrate catabolism in facultative anaerobes such as oysters is reduced during transition to the pessimum range of tolerance to environmental stressors (Sokolova et al., 2012), which could explain similar GLY content observed between low $(\mathrm{pH}$ 7.8) and high hypercapnia ( $\mathrm{pH}$ 7.0). Similarly, Mytilus galloprovincialis mussels presented low energetic expenditure (high GLY content) when exposed to hypercapnia (Freitas et al., 2017). Metabolic depression is only a time limited mechanism to endure extreme stress, and therefore the impacts of extended exposure to hypercapnia likely pose greater challenges to this species.

\section{Concluding remarks}

The present study brings new insights on two important oyster species biochemical responses to hypercapnia. Our data show marked differences in each species response pattern to this environmental stressor, in accordance with other studies assessing comparative performances between other closely related bivalve species enduring abiotic stress, namely Mytilid (Tomanek, 2014) and Venerid (Velez et al., 2016) congeners. An opposite trend was demonstrated regarding metabolic potential between both species, assessed by the electron transport system activity, with $C$. gigas presenting increased metabolic capacity (ETS) with the increase of hypercapnia. Higher antioxidant capacity observed in $C$. gigas, demonstrated by the increase of antioxidant enzymes SOD and CAT, as well as changes in non-enzymatic ROS scavenger GSH oxidation form and concentration, indicate that these conditions induced a prooxidant status. Our data further show that $C$. gigas employed GSH as preferential antioxidant to cope with hypercapnia induced oxidative stress, with observed effects on the glutathione pool (tGSH) and GSH/GSSG, most evident for juvenile specimens at the highest hypercapnia level. The antioxidant capacity of C. gigas resulted in no increase of cellular damage (LPO), except for juveniles held at the intermediate hypercapnic level. Nonetheless, data on GSH mediated antioxidant response suggest that this mechanism is time limited.

In contrast, $C$. brasiliana presented a decrease of metabolic potential, noted by lower ETS activity with the increase of hypercapnia. These results suggest metabolic depression to withstand hypercapnia by this species, and were further supported by low antioxidant capacity, no change or even decrease (juveniles at $\mathrm{pH}$ 7.0) of LPO, indicating reduced aerobic scope to sustain energetic fitness under hypercapnia.

These results highlight different strategies to cope with increased $p \mathrm{CO}_{2}$ by different oyster species, bringing new insights on species tolerance capacity and differentiated response mechanisms. The time duration of environmental hypercapnia in estuarine systems may be of upmost importance, since oyster response mechanisms to high environmental $p \mathrm{CO}_{2}$ suggest to be time limited. According to the energylimited tolerance concept (Sokolova et al., 2012) our study indicates that the mangrove oyster ( $C$. brasiliana) transitioned into the pessimum tolerance range under hypercapnia as a conservation mechanism to endure extreme stress, while the pacific oyster (C. gigas) response patterns reflected a moderate stress status, which can generally imply a wider range of tolerance towards hypercapnia than C. brasiliana, as well as a longer and more sustainable energetic balance. The differentiated response pattern observed can have further implications at the population level, and therefore may influence species competitive advantages towards one another in a hypercapnic environment. In a scenario of coexistence of the two species in the same areas, it appears that $C$. gigas may be more resilient than the native species (C. brasiliana) to environmental hypercapnia, with ecological repercussions that are dificult to predict. Therefore, efforts should be made to prevent the spread of the non-native species into pristine environments where $C$. brasiliana still thrives.

\section{Acknowledgements}

This study was supported by the Portuguese Science Foundation (FCT) through CESAM: UID/AMB $/ 50017 / 2013$. Anthony Moreira benefited from $\mathrm{PhD}$ grant SFRH/BD/93107/2013. Rosa Freitas benefited from post-doc grant SFRH/BPD/92258/2013 financed by the Portuguese Science Foundation (FCT). The authors would like to thank Mr. Francisco Coutinho from the Mandira Community at the Cananéia Natural Reserve for aiding on the collection of $C$. brasiliana specimens, and the Laboratory of Marine Mollusks of the University of Santa Catarina staff for providing C. gigas.

\section{Appendix A. Supplementary material}

Supplementary data associated with this article can be found in the online version at http://dx.doi.org/10.1016/j.envres.2017.10.035.

\section{References}

Abele, D., Philipp, E., Gonzalez, P., Puntarulo, S., 2007. Marine invertebrate mitochondria and oxidative stress. Front. Biosci. 12, 933-946.

Anderson, M., Gorley, R.N., Clarke, R.K., 2008. Permanova + for Primer: Guide to Software and Statisticl Methods.

Anestis, A., Lazou, A., Pörtner, H.O., Michaelidis, B., 2007. Behavioral, metabolic, and molecular stress responses of marine bivalve Mytilus galloprovincialis during long-term acclimation at increasing ambient temperature. Am. J. Physiol.-Regul., Integr. Comp. Physiol. 293, R911-R921.

Beauchamp, C., Fridovich, I., 1971. Superoxide dismutase: improved assays and an assay applicable to acrylamide gels. Anal. Biochem. 44, 276-287. http://dx.doi.org/10. 1016/0003-2697(71)90370-8.

Buege, J.A., Aust, S.D., 1978. [30] Microsomal lipid peroxidation. Methods Enzymol. Biomembr. - Part C: Biol. Oxid. 52, 302-310. http://dx.doi.org/10.1016/S00766879(78)52032-6.

Burnett, L.E., 1997. The Challenges of Living in Hypoxic and Hypercapnic Aquatic Environments. Am. Zool. 37, 633-640. http://dx.doi.org/10.1093/icb/37.6.633.

Byers, J.E., 2002. Impact of non-indigenous species on natives enhanced by anthropogenic alteration of selection regimes. Oikos 97, 449-458. http://dx.doi.org/10. 1034/j.1600-0706.2002.970316.x.

Cai, W.-J., 2011. Estuarine and coastal ocean carbon paradox: $\mathrm{CO}_{2}$ sinks or sites of terrestrial carbon incineration? Annu. Rev. Mar. Sci. 3, 123-145. http://dx.doi.org/10. 1146/annurev-marine-120709-142723.

Coen, W.M.D., Janssen, C.R., 1997. The use of biomarkers in Daphnia magna toxicity testing. IV. Cellular Energy Allocation: a new methodology to assess the energy budget of toxicant-stressed Daphnia populations. J. Aquat. Ecosyst. Stress Recovery 6 43-55. http://dx.doi.org/10.1023/A:1008228517955.

Almeida, E.A., Bainy, A.C.D., de Melo Loureiro, A.P., Martinez, G.R., Miyamoto, S. Onuki, J., Barbosa, L.F., Garcia, C.C.M., Prado, F.M., Ronsein, G.E., et al., 2007. 
Oxidative stress in Perna perna and other bivalves as indicators of environmental stress in the Brazilian marine environment: antioxidants, lipid peroxidation and DNA damage. Comp. Biochem. Physiol. Part A: Mol. Integr. Physiol. 146, 588-600.

Beck, M.W., Brumbaugh, R.D., Airoldi, L., Carranza, A., Coen, L.D., Crawford, C., Defeo, O., Edgar, G.J., Hancock, B., Kay, M.C., Lenihan, H.S., Luckenbach, M.W., Toropova, C.L., Zhang, G., Guo, X., 2011. Oyster reefs at risk and recommendations for conservation, restoration, and management. BioScience 61, 107-116. http://dx.doi.org/ 10.1525/bio.2011.61.2.5.

Dickinson, G.H., Ivanina, A.V., Matoo, O.B., Pörtner, H.O., Lannig, G., Bock, C., Beniash, E., Sokolova, I.M., 2012. Interactive effects of salinity and elevated $\mathrm{CO}_{2}$ levels on juvenile eastern oysters, Crassostrea virginica. J. Exp. Biol. 215, 29-43. http://dx.doi. org/10.1242/jeb.061481.

Dickson, A.G., 1990. Standard potential of the reaction: $\mathrm{AgCl}(\mathrm{s})+12 \mathrm{H}_{2}(\mathrm{~g})=\mathrm{Ag}(\mathrm{s})+$ $\mathrm{HCl}(\mathrm{aq})$, and and the standard acidity constant of the ion $\mathrm{HSO}_{4}-$ in synthetic sea water from 273.15 to $318.15 \mathrm{~K}$. J. Chem. Thermodyn. 22, 113-127. http://dx.doi. org/10.1016/0021-9614(90)90074-Z.

Dickson, A.G., Millero, F.J., 1987. A comparison of the equilibrium constants for the dissociation of carbonic acid in seawater media. Deep Sea Res. Part A Oceanogr. Res. Pap. 34, 1733-1743. http://dx.doi.org/10.1016/0198-0149(87)90021-5.

Duarte, G., Calderon, E.N., Pereira, C.M., Marangoni, L.F.B., Santos, H.F., Peixoto, R.S., Bianchini, A., Castro, C.B., 2015. A novel marine mesocosm facility to study global warming, water quality, and ocean acidification. Ecol. Evol. 5, 4555-4566. http://dx. doi.org/10.1002/ece3.1670.

Evans, W., Hales, B., Strutton, P.G., 2013. pCO 2 distributions andair-water CO 2 fluxes in the Columbia River estuary. Estuar. Coast. Shelf Sci. 117, 260-272.

Feely, R.A., Alin, S.R., Newton, J., Sabine, C.L., Warner, M., Devol, A., Krembs, C., Maloy, C., 2010. The combined effects of ocean acidification, mixing, and respiration on $\mathrm{pH}$ and carbonate saturation in an urbanized estuary. Estuar., Coast. Shelf Sci. 88, 442-449. http://dx.doi.org/10.1016/j.ecss.2010.05.004.

Frankignoulle, M., Abril, G., Borges, A., Bourge, I., Canon, C., Delille, B., Libert, E Théate, J.-M., 1998. Carbon dioxide emission from European estuaries. Science 282, 434-436. http://dx.doi.org/10.1126/science.282.5388.434.

Freitas, R., Almeida, Â., Calisto, V., Velez, C., Moreira, A., Schneider, R.J., Esteves, V.I., Wrona, F.J., Figueira, E., Soares, A.M.V.M., 2016. The impacts of pharmaceutical drugs under ocean acidification: new data on single and combined long-term effects of carbamazepine on Scrobicularia plana. Sci. Total Environ. 541, 977-985. http://dx. doi.org/10.1016/j.scitotenv.2015.09.138.

Freitas, R., De Marchi, L., Bastos, M., Moreira, A., Velez, C., Chiesa, S., Wrona, F.J., Figueira, E., Soares, A.M.V.M., 2017. Effects of seawater acidification and salinity alterations on metabolic, osmoregulation and oxidative stress markers in Mytilus galloprovincialis. Ecol. Indic. 79, 54-62. http://dx.doi.org/10.1016/j.ecolind.2017. 04.003.

Garcia, J., Han, D., Sancheti, H., Yap, L.-P., Kaplowitz, N., Cadenas, E., 2010. Regulation of mitochondrial glutathione redox status and protein glutathionylation by respiratory substrates. J. Biol. Chem. 285, 39646-39654. http://dx.doi.org/10.1074/ jbc.M110.164160.

García-Esquivel, Z., Bricelj, V.M., Felbeck, H., 2002. Metabolic depression and wholebody response to enforced starvation by Crassostrea gigas postlarvae. Comp. Biochem. Physiol. Part A: Mol. Integr. Physiol. 133, 63-77.

Gazeau, F., Rijswijk, P., van, Pozzato, L., Middelburg, J.J., 2014. Impacts of Ocean acidification on sediment processes in shallow waters of the Arctic Ocean. PLoS One 9, e94068. http://dx.doi.org/10.1371/journal.pone.0094068.

Ghezzi, P., Di Simplicio, P., 2009. Protein glutathiolation. In: Junioressor, J.-P.C.J., Winyardessor, P.G. (Eds.), Redox Signaling and Regulation in Biology and Medicine. Wiley-VCH Verlag GmbH \& Co. KGaA, pp. 123-141.

Gibbin, E.M., Chakravarti, L.J., Jarrold, M.D., Christen, F., Turpin, V., N'Siala, G.M., Blier, P.U., Calosi, P., 2017. Can multi-generational exposure to ocean warming and acidification lead to the adaptation of life history and physiology in a marine metazoan? J. Exp. Biol. 220, 551-563. http://dx.doi.org/10.1242/jeb.149989.

Grabowski, J.H., Brumbaugh, R.D., Conrad, R.F., Keeler, A.G., Opaluch, J.J., Peterson, C.H., Piehler, M.F., Powers, S.P., Smyth, A.R., 2012. Economic valuation of ecosystem services provided by oyster reefs. BioScience 62, 900-909. http://dx.doi.org/10. 1525/bio.2012.62.10.10

Guppy, M., Withers, P., 1999. Metabolic depression in animals: physiological perspectives and biochemical generalizations. Biol. Rev. Camb. Philos. Soc. 74, 1-40.

Guzy, R.D., Schumacker, P.T., 2006. Oxygen sensing by mitochondria at complex III: the paradox of increased reactive oxygen species during hypoxia. Exp. Physiol. 91 807-819.

Han, D., Hanawa, N., Saberi, B., Kaplowitz, N., 2006. Mechanisms of Liver Injury. III. Role of glutathione redox status in liver injury. Am. J. Physiol. - Gastrointest. Liver Physiol. 291, G1-G7. http://dx.doi.org/10.1152/ajpgi.00001.2006.

Hannam, M.L., Bamber, S.D., Moody, A.J., Galloway, T.S., Jones, M.B., 2010. Immunotoxicity and oxidative stress in the Arctic scallop Chlamys islandica: effects of acute oil exposure. Ecotoxicol. Environ. Saf. 73, 1440-1448. http://dx.doi.org/10. 1016/j.ecoenv.2010.06.012.

Harms, L., Frickenhaus, S., Schiffer, M., Mark, F.C., Storch, D., Held, C., Pörtner, H.-O Lucassen, M., 2014. Gene expression profiling in gills of the great spider crab Hyas araneus in response to ocean acidification and warming. BMC Genom. 15, 789. http://dx.doi.org/10.1186/1471-2164-15-789.

Hawkins, B.J., Irrinki, K.M., Mallilankaraman, K., Lien, Y.-C., Wang, Y., Bhanumathy, C.D., Subbiah, R., Ritchie, M.F., Soboloff, J., Baba, Y., Kurosaki, T., Joseph, S.K., Gill, D.L., Madesh, M., 2010. S-glutathionylation activates STIM1 and alters mitochondrial homeostasis. J. Cell Biol. 190 (3), 391-405. http://dx.doi.org/10.1083/jcb. 201004152. (jcb.201004152).

Hurd, T.R., Costa, N.J., Dahm, C.C., Beer, S.M., Brown, S.E., Filipovska, A., Murphy, M.P., 2005. Glutathionylation of mitochondrial proteins. Antioxid. Redox Signal. 7,
999-1010. http://dx.doi.org/10.1089/ars.2005.7.999.

IPCC, 2013. Summary for policymakers. In: Stocker, T.F., Qin, D., Plattner, G.-K., Tignor, M., Allen, S.K., Boschung, J., Nauels, A., Xia, Y., Bex, V., Midgley, P.M. (Eds.), Climate Change 2013: The Physical Science BasisContribution of Working Group I to the Fifth Assessment Report of the Intergovernmental Panel on Climate Change. Cambridge University Press, Cambridge, United Kingdom and New York, NY, USA, pp. 1-30.

Johansson, L.H., Håkan Borg, L.A., 1988. A spectrophotometric method for determination of catalase activity in small tissue samples. Anal. Biochem. 174, 331-336. http://dx. doi.org/10.1016/0003-2697(88)90554-4.

Khan, B., Ringwood, A.M., 2016. Cellular biomarker responses to hypoxia in eastern oysters and Atlantic ribbed marsh mussels. Mar. Ecol. Prog. Ser. 546, 123-133. http://dx.doi.org/10.3354/meps11622.

King, F.D., Packard, T.T., 1975. Respiration and the activity of the respiratory electron transport system in marine zooplankton1. Limnol. Oceanogr. 20, 849-854. http://dx. doi.org/10.4319/lo.1975.20.5.0849.

Langenbuch, M., Pörtner, H.O., 2003. Energy budget of hepatocytes from Antarctic fish (Pachycara brachycephalum and Lepidonotothen kempi) as a function of ambient $\mathrm{CO}_{2}$ : ph-dependent limitations of cellular protein biosynthesis? J. Exp. Biol. 206, 3895-3903. http://dx.doi.org/10.1242/jeb.00620.

Lannig, G., Eilers, S., Pörtner, H.O., Sokolova, I.M., Bock, C., 2010. Impact of ocean acidification on energy metabolism of oyster, Crassostrea gigas -changes in metabolic pathways and thermal response. Mar. Drugs 8, 2318-2339. http://dx.doi.org/10. $3390 / \mathrm{md} 8082318$

Le Moullac, G., Quéau, I., Le Souchu, P., Pouvreau, S., Moal, J., René Le Coz, J., François Samain, J.,, 2007. Metabolic adjustments in the oyster Crassostrea gigas according to oxygen level and temperature. Mar. Biol. Res. 3, 357-366.

Lindinger, M.I., Lauren, D.J., Mcdonald, D.G., 1984. Acid-base balance in the sea mussel, Mytilus edulis. III. Effects of environmental hypercapnia on intra- and extracellular acid-base balance. Mar. Biol. Lett. 5, 371-381.

Matoo, O.B., Ivanina, A.V., Ullstad, C., Beniash, E., Sokolova, I.M., 2013. Interactive effects of elevated temperature and $\mathrm{CO}_{2}$ levels on metabolism and oxidative stress in two common marine bivalves (Crassostrea virginica and Mercenaria mercenaria). Comp. Biochem. Physiol. Part A: Mol. Integr. Physiol. 164, 545-553. http://dx.doi. org/10.1016/j.cbpa.2012.12.025.

Mehrbach, C., Culberson, C.H., Hawley, J.E., Pytkowicx, R.M., 1973. Measurement of the apparent dissociation constants of carbonic acid in seawater at atmospheric pressure. Limnol. Oceanogr. 18, 897-907. http://dx.doi.org/10.4319/lo.1973.18.6.0897.

Melo, C.M.R., Silva, F.C., Gomes, C.H.A.M., Solé-Cava, A.M., Lazoski, C., 2009. Crassostrea gigas in natural oyster banks in southern Brazil. Biol. Invasions 12 , 441-449. http://dx.doi.org/10.1007/s10530-009-9475-7.

Melo, A.G.C., de, Varela, E.S., Beasley, C.R., Schneider, H., Sampaio, I., Gaffney, P.M., Reece, K.S., Tagliaro, C.H., 2010. Molecular identification, phylogeny and geographic distribution of Brazilian mangrove oysters (Crassostrea). Genet. Mol. Biol. 33, 564-572. http://dx.doi.org/10.1590/S1415-47572010000300030.

Melzner, F., Gutowska, M.A., Langenbuch, M., Dupont, S., Lucassen, M., Thorndyke, M.C., Bleich, M., Pörtner, H.-O., 2009. Physiological basis for high $\mathrm{CO}_{2}$ tolerance in marine ectothermic animals: pre-adaptation through lifestyle and ontogeny? Biogeosciences 6, 2313-2331.

Melzner, F., Thomsen, J., Koeve, W., Oschlies, A., Gutowska, M.A., Bange, H.W., Hansen, H.P., Körtzinger, A., 2013. Future ocean acidification will be amplified by hypoxia in coastal habitats. Mar. Biol. 160, 1875-1888. http://dx.doi.org/10.1007/s00227-012 1954-1.

Mendonça, J.T., Machado, I.C., 2010. Mangrove oyster (Crassostrea spp.) (Sacco, 1897) extractivism in Cananéia estuary (São Paulo, Brazil) from 1999 to 2006: capture and management evaluation. Braz. J. Biol. 70, 65-73. http://dx.doi.org/10.1590/S151969842010000100010

Michaelidis, B., Ouzounis, C., Paleras, A., Prtner, H.O., 2005. Effects of long-term moderate hypercapnia on acid-base balance and growth rate in marine mussels Mytilus galloprovincialis. Mar. Ecol. Prog. Ser. 293, 109-118. http://dx.doi.org/10.3354/ meps293109.

Moreira, A., Figueira, E., Pecora, I.L., Soares, A.M.V.M., Freitas, R., 2017. iochemical alterations in native and exotic oyster species in Brazil inresponse to increasing temperature. Comp. Biochem. Physiol. Part C Toxicol.Pharmacol. 191, 183-193. http://dx.doi.org/10.1016/j.cbpc.2016.10.008.

Moreira, A., Figueira, E., Soares, A.M.V.M., Freitas, R., 2016. Salinity influences the biochemical response of Crassostrea angulata to Arsenic. Environ. Pollut. 214, 756-766. http://dx.doi.org/10.1016/j.envpol.2016.04.036.

Müller, M., Mentel, M., van Hellemond, J.J., Henze, K., Woehle, C., Gould, S.B., Yu, R.-Y., van der Giezen, M., Tielens, A.G.M., Martin, W.F., 2012. Biochemistry and evolution of anaerobic energy metabolism in eukaryotes. Microbiol. Mol. Biol. Rev. 76, 444-495. http://dx.doi.org/10.1128/MMBR.05024-11.

Murphy, M.P., 2009. How mitochondria produce reactive oxygen species. Biochem. J. $417,1-13$

Nardi, A., Mincarelli, L.F., Benedetti, M., Fattorini, D., d'Errico, G., Regoli, F., 2017. Indirect effects of climate changes on cadmium bioavailability and biological effects in the Mediterranean mussel Mytilus galloprovincialis. Chemosphere 169, 493-502. http://dx.doi.org/10.1016/j.chemosphere.2016.11.093.

Neto, R.M., Zeni, T.O., Ludwig, S., Horodesky, A., Girotto, M.V.F., Castilho-Westphal, G.G., Ostrensky, A., 2013. Influence of environmental variables on the growth and reproductive cycle of Crassostrea (Mollusca, Bivalvia) in Guaratuba Bay, Brazil. Invertebr. Reprod. Dev. 57, 208-218. http://dx.doi.org/10.1080/07924259.2012 747449.

Noriega, C., Araujo, M., 2014. Carbon dioxide emissions from estuaries of northern and northeastern Brazil. Sci. Rep. 4, 6164. http://dx.doi.org/10.1038/srep06164.

Pannunzio, T.M., Storey, K.B., 1998. Antioxidant defenses and lipid peroxidation during 
anoxia stress and aerobic recovery in the marine gastropod Littorina littorea. J. Exp. Mar. Biol. Ecol. 221, 277-292.

Parker, L.M., Ross, P.M., O’Connor, W.A., Pörtner, H.O., Scanes, E., Wright, J.M., 2013. Predicting the response of molluscs to the impact of Ocean acidification. Biol. (Basel) 2, 651-692. http://dx.doi.org/10.3390/biology2020651.

Peña-Llopis, S., Ferrando, M.D., Peña, J.B., 2002. Impaired glutathione redox status is associated with decreased survival in two organophosphate-poisoned marine bivalves. Chemosphere 47, 485-497. http://dx.doi.org/10.1016/S0045-6535(01) 00323-X.

Philipp, E.E., Schmidt, M., Gsottbauer, C., Sänger, A.M., Abele, D., 2008. Size-and agedependent changes in adductor muscle swimming physiology of the scallop Aequipecten opercularis. J. Exp. Biol. 211, 2492-2501.

Pörtner, H.-O., 2010. Oxygen- and capacity-limitation of thermal tolerance: a matrix for integrating climate-related stressor effects in marine ecosystems. J. Exp. Biol. 213, 881-893. http://dx.doi.org/10.1242/jeb.037523.

Pörtner, H.O., Langenbuch, M., Michaelidis, B., 2005. Synergistic effects of temperature extremes, hypoxia, and increases in $\mathrm{CO}_{2}$ on marine animals: from Earth history to global change. J. Geophys. Res. 110, C09S10. http://dx.doi.org/10.1029/ 2004JC002561.

Pörtner, H.O., Langenbuch, M., Reipschläger, A., 2004. Biological impact of elevated ocean $\mathrm{CO}_{2}$ concentrations: lessons from animal physiology and earth history. J. Oceanogr. 60, 705-718.

Pörtner, H.O., Reipschläger, A., Heisler, N., 1998. Acid-base regulation, metabolism and energetics in Sipunculus nudus as a function of ambient carbon dioxide level. J. Exp. Biol. 201, 43-55.

Rahman, I., Kode, A., Biswas, S.K., 2007. Assay for quantitative determination of glutathione and glutathione disulfide levels using enzymatic recycling method. Nat. Protoc. 1, 3159-3165. http://dx.doi.org/10.1038/nprot.2006.378.

Regoli, F., Nigro, M., Orlando, E., 1998. Lysosomal and antioxidant responses to metals in the Antarctic scallop Adamussium colbecki. Aquat. Toxicol. 40, 375-392. http://dx. doi.org/10.1016/S0166-445X(97)00059-3.

Reipschläger, A., Pörtner, H.-O., 1996. Metabolic depression during environmental stress: the role of extracellular versus intracellular pH in sipunculus nudus. J. Exp. Biol. 199, 1801-1807.

Ringwood, A.H., Conners, D.E., Keppler, C.J., 1999. Cellular responses of oysters, Crassostrea virginica, to metal-contaminated sediments. Mar. Environ. Res. 48 427-437. http://dx.doi.org/10.1016/S0141-1136(99)00062-8.

Ringwood, A.H., Keppler, C.J., 2002. Water quality variation and clam growth: is $\mathrm{pH}$ really a non-issue in estuaries? Estuaries 25, 901-907. http://dx.doi.org/10.1007/ BF02691338.

Rivera-Ingraham, G.A., Rocchetta, I., Meyer, S., Abele, D., 2013. Oxygen radical formation in anoxic transgression and anoxia-reoxygenation: foe or phantom? Experiments with a hypoxia tolerant bivalve. Mar. Environ. Res. 92, 110-119. http://dx.doi.org/ 10.1016/j.marenvres.2013.09.007.

Robbins, L.L., Hansen, M.E., Kleypas, J.A., Meylan, S.C., 2010. CO 2 Calc: a User-Friendly Seawater Carbon Calculator for Windows, Mac OS X, and iOS (iPhone) (USGS Numbered Series No. 2010-1280). Open-File Report U.S. Geological Survey, Reston, VA.

Robinson, H.W., Hogden, C.G., et al., 1940. The biuret reaction in the determination of serum proteins. 1. A study of the conditions necessary for the production of a stable color which bears a quantitative relationship to the protein concentration. J. Biol. Chem. 135, 707-725.

Samain, J.-F., McCombie, H., 2008. Summer Mortality of Pacific Oyster Crassostrea Gigas: The Morest Project. Editions Quae.

Schmidlin, L., von Fumetti, S., Nagel, P., 2015. Temperature effects on the feeding and electron transport system (ETS) activity of Gammarus fossarum. Aquatic Ecol. 49. pp. 71-80.

Shirayama, Y., Thornton, H., 2005. Effect of increased atmospheric $\mathrm{CO}_{2}$ on shallow water marine benthos. J. Geophys. Res. 110, C09S08. http://dx.doi.org/10.1029/ 2004JC002618.

Simpson, D.P., 1967. Regulation of renal citrate metabolism by bicarbonate ion and $\mathrm{pH}$ : observations in tissue slices and mitochondria. J. Clin. Investig. 46, 225.

Sokolova, I.M., Frederich, M., Bagwe, R., Lannig, G., Sukhotin, A.A., 2012. Energy homeostasis as an integrative tool for assessing limits of environmental stress tolerance in aquatic invertebrates. Mar. Environ. Res. 79, 1-15. http://dx.doi.org/10. 1016/j.marenvres.2012.04.003.

Sokolova, I.M., Lannig, G., 2008. Interactive effects of metal pollution and temperature on metabolism in aquatic ectotherms: implications of global climate change. Clim. Res. 37, 181-201.

Somero, G.N., 2010. The physiology of climate change: how potentials for acclimatization and genetic adaptation will determine "winners" and "losers.". J. Exp. Biol. 213, 912-920. http://dx.doi.org/10.1242/jeb.037473.

Storey, K.B., 1998. Survival under stress: molecular mechanisms of metabolic rate depression in animals. S. Afr. J. Zool. 33, 55-64.

Strobel, A., Graeve, M., Poertner, H.O., Mark, F.C., 2013. Mitochondrial acclimation capacities to ocean warming and acidification are limited in the Antarctic Nototheniid Fish, Notothenia rossii and Lepidonotothen squamifrons. PLoS One 8, e68865. http://dx.doi.org/10.1371/journal.pone.0068865.

Timmins-Schiffman, E., Coffey, W.D., Hua, W., Nunn, B.L., Dickinson, G.H., Roberts, S.B., 2014. Shotgun proteomics reveals physiological response to ocean acidification in Crassostrea gigas. BMC Genom. 15, 951. http://dx.doi.org/10.1186/1471-2164-15 951.

Tomanek, L., 2015. Proteomic responses to environmentally induced oxidative stress. J. Exp. Biol. 218, 1867-1879. http://dx.doi.org/10.1242/jeb.116475.

Tomanek, L., 2014. Proteomics to study adaptations in marine organisms to environmental stress. J. Proteom. Spec. Issue.: Proteom. Non-Model Org. 105, 92-106. http://dx.doi.org/10.1016/j.jprot.2014.04.009.

Tomanek, L., Zuzow, M.J., Ivanina, A.V., Beniash, E., Sokolova, I.M., 2011. Proteomic response to elevated $\mathrm{PCO}_{2}$ level in eastern oysters, Crassostrea virginica: evidence for oxidative stress. J. Exp. Biol. 214, 1836-1844. http://dx.doi.org/10.1242/jeb. 055475 .

Velez, C., Figueira, E., Soares, A.M.V.M., Freitas, R., 2016. Native and introduced clams biochemical responses to salinity and $\mathrm{pH}$ changes. Sci. Total Environ. 566-567, 260-268. http://dx.doi.org/10.1016/j.scitotenv.2016.05.019.

Willson, L.L., Burnett, L.E., 2000. Whole animal and gill tissue oxygen uptake in the Eastern oyster, Crassostrea virginica: effects of hypoxia, hypercapnia, air exposure, and infection with the protozoan parasite Perkinsus marinus. J. Exp. Mar. Biol. Ecol 246, 223-240. http://dx doi.org/10.1016/S0022-0981(99)00183-5.

Yoshikawa, H., 1959. Glycogen. Rinsho Ikagaku Kyodoisho, Tokyo, pp. 150-152. 